\title{
Innovation in Public Services Through the Kawi Smara Program at Klungkung Regency
}

\author{
Ida Ayu Putu Sri Widnyani ${ }^{1}$, I Made Siswambara ${ }^{2}$ \\ ${ }^{1}$ Magister Ilmu Administrasi, Ngurah Rai University, Jl. Padma Penatih, Denpasar, Indonesia \\ (email: dayusriwid@gmail.com), \\ ${ }^{2}$ Magister Ilmu Administrasi, Ngurah Rai University, Jl. Padma Penatih, Denpasar, Indonesia \\ (email: siswambara@gmail.com)
}

\begin{abstract}
This study aims to determine (1) the effectiveness of the Kawi Smara Innovation Program in improving the quality of public services at Klungkung Regency (2) factors are the inhibitors of the effectiveness of the Kawi Smara Innovation Program in improving the quality of public at Klungkung Regency. This study employed the qualitative descriptive methodology. The results of this study indicate that (1) the implementation of Kawi Smara's innovation program has been effective in terms of service quality, this innovation program has proven to greatly facilitate the public to obtain a marriage certificate, this innovation program has advantages in terms of the speed of the marriage certificate. the solution for the people who want to do their marriage ceremony right away is to get their marriage certificate. The Kawi Smara program is not maximally in quantity, the target of Kawi Smara's innovation program has not been maximally achieved, this is evidenced by the still low percentage of people who follow Kawi Smara's innovative program services. (2) Factors that hinder the effectiveness of the Kawi Smara innovation program at Klungkung Regency based on the results of the study are Lack of socialization, low public awareness and budget constraints.
\end{abstract}

\section{Keywords:}

innovation; public service; Kawi Smara

\section{Introduction}

In order to accelerate the development process towards a superior and prosperous Klungkung community, the government of Klungkung Regency began to announce the Political and Innovative Community Movement (Gema Santi). Gema Santi is the implementation of the Mental Revolution Movement and the Bali Mandara Program and it is hoped that by making these programs, each SKPD head can be more creative and innovate to get new ideas that are truly felt by the Klungkung community. The flagship program of 
Gema Santi (Social and Innovative Community Movement) Office of Population and Civil Registration in Klungkung Regency Especially in the Field of Civil Registration Services is Bela Nanda or Once Born Children Get Birth Certificates, Kawi Smara or Giving a Marriage Certificate when Conducting Marriage Ceremony and Pitra Bakti Services or Services Integrated in the Issuance of Death Certificate. In this study, researchers limited the Kawi Smara program in the Department of Population and Civil Registration of Klungkung Regency. Based on observations of the implementation of the duties and functions of the civil registration service especially marriage registration services for 2 (two) years, it can be identified several problems faced by the Population and Civil Registry Office (Disdukcapil) prior to the Kawi Smara Innovation, among others as follows:

1. The problem of a marriage certificate is a complicated problem for the community where people are reluctant to take care of their own marriage certificate. With the innovation of Kawi Smara (Giving a Marriage Certificate when Implementing a Marriage Ceremony), it is hoped that it can help the community in the process of making a marriage certificate;

2. The number of ownership of marriage certificates in Klungkung Regency is still low. The 2018 marriage certificate ownership table can be seen in the following table:

Table 1.

Number of data of Marriage Certificate ownership in Klungkung Regency

\begin{tabular}{|c|c|c|c|}
\hline Year & $\begin{array}{l}\text { Number } \\
\text { of } \\
\text { Married } \\
\text { Couples }\end{array}$ & $\begin{array}{l}\text { Total } \\
\text { ownership } \\
\text { of } \\
\text { marriage } \\
\text { certificate }\end{array}$ & $\begin{array}{c}\text { Percentage } \\
(\%)\end{array}$ \\
\hline 2017 & 55.422 & 35.180 & 63,48 \\
\hline 2018 & 56.051 & 37.320 & 66,58 \\
\hline \multicolumn{4}{|c|}{$\begin{array}{l}\text { Source : SIAK Office of Population and } \\
\text { Civil Registry of Klungkung Regency } \\
2019\end{array}$} \\
\hline
\end{tabular}

3. There are still many unregistered marriages, so many marriages that are considered unlawful. The child only has a civil relationship with mother and family; 
4. Marriage certificate services at the Office of Population and Civil Registry of Klungkung Regency are only limited to the office, this will make it difficult for people who live far from the office, especially in the Nusa Penida islands, this makes the service innovate to carry out mobile services in the deed service marriage is the Kawi Smara program.

\section{Methods}

This research employed the qualitative descriptive approach, with the location of study at Klungkung Regency, Bali Province. The technique used in selecting the informans was purposive. This study gathered two types of data, which are primary and secondary data. The data collection technique used were literature study, observation, and interviews.

\section{Results and Discussion}

\section{Kawi Smara as an Marriage Certificate Services Innovation}

Kawi Smara (Giving a Marriage Certificate When Implementing a Marriage Ceremony) is the Population and Civil Registry Office of Klungkung innovation in increasing the scope of ownership of a marriage certificate. With Kawi Smara the bride and groom immediately get a marriage certificate once the marriage ceremony is over. Kawi Smara cut the bureaucratic chain in arranging a marriage certificate. The signing of the pemuput/ priest will be carried out at the location of the marriage ceremony, including the signing of the village, the bride and the witnesses. Kawi Smara really helped the bride and groom in providing the legality of their marriage. In the midst of busy preparing for the wedding ceremony the bride or bride groom's family can submit a request to the Population and Civil Registry Office, this can avoid neglect in the management of the marriage certificate.

Public service innovation is the application of new ideas in organizing the fulfillment of the wants and needs of the community by the state organizer so that the community can meet their needs. public service quality is the totality of the ability of service providers in providing services for products (goods or services) and administrative services to customers / communities, which can meet the needs and can provide satisfaction to customers based on conformity with expectations and reality received by customers / communities ". 
Budiani Opinion Kowaas A.S, et.al (2017) mentions several indicators used to measure effectiveness are as follows:

1. Accuracy of program goals, i.e. the extent to which the participants of the program are precisely predetermined.

2. Program socialization, namely the ability of program implementation in conducting program socialization so that information regarding the implementation of the program can be conveyed to the community in general and the target audience of programs in particular. According to Wilcox in Mardikonto (2013, p. 86), Providing information is the initial step taken to obtain maximum results and facilitate the continuing work, because by providing information can be used and increase knowledge for people who receive the information

3. Program objectives, i.e. the extent of compatibility between the program results and program objectives that have been previously determined.

4. Program monitoring, i.e. activities carried out after the program is implemented as a form of attention to program participants.

Measurement of effectiveness is used to see the extent to which activeness, usability, conformity in an activity of the person carrying out with the intended target. This effectiveness measurement is used to get the effectiveness of a goal by looking at various indicators of a program. The Kawi Smara innovation program is one of the innovations of the Klungkung Regency's Population and Civil Registry Office with the aim of making it easier for the community to obtain a marriage certificate, increase the scope of ownership of a marriage certificate and ensure the legality of each marriage carried out by the community.

\section{The Effectiveness of the Kawi Smara Program as an Innovation in Marriage Certificate Services}

The effectiveness of the Kawi Smara innovation program at the Department of Population and Civil Registration at Klungkung Regency, based on the opinion of Budiani in Kowaas A.S, et.al (2017) mentions several indicators used to measure effectiveness, namely 
the accuracy of program targets, program socialization, program objectives and program monitoring.

1. Accuracy of program goals Namely the extent to which the program participants precisely predetermined.

According to Makmur (2011, p. 8) accuracy of targets is more oriented to the short term and more operational, determining the right goals both individually determined and the goals set by the organization actually determine the success of organizational activities. Likewise, if the target set is not right it will hamper the implementation of the various activities themselves.

A program implemented by the government should have the right target because the accuracy of the target in every program implementation becomes one of the aspects that influences the success of a program in achieving the expected goals. The purpose of the program objectives is to see the extent to which the participants of the program have been determined in advance. Based on the results of good research conducted to service providers and service recipients as the target group of the Kawi Smara innovation program shows that the Kawi Smara innovation program on the accuracy of the quality of the program target accuracy is effective but in quantity is still not optimal, this is evidenced by the still low percentage of the community which implements marriages that participate in the Kawi Smara innovation program services compared to the people who carry out marriages. In 2017, only $11.98 \%$ of the people who implemented marriages participated in the Kawi Smara innovation program. In 2018, only $25.02 \%$ of people implementing marriages that participated in the Kawi Smara innovation program, this is because there are still many people who do not know about the Kawi Smara innovation program, the requirements have not been met and still consider the administration of convoluted marriage certificates and charged.

2. Program socialization, namely the ability to organize programs in conducting socialization program so that information about program implementation can be conveyed to the community in general and to program participants in particular. According to Wilcox in Mardikonto (2013, p. 86), Providing information is the initial step 
taken to obtain maximum results and facilitate the continuing work, because by providing information can be used and increase knowledge for people who receive the information.

Indicators of program socialization, socialization is the main key to the success of a program in achieving the expected goals and objectives. Through an effective socialization process to the community, a program will easily achieve success in its implementation. Program socialization is the starting point that determines success in achieving its goals, therefore program socialization must be carried out in a planned and systematic manner so that planned objectives are achieved well, it happens because the better the program's socialization process will be better the public's understanding of the concept and the purpose of a program. In a policy, program socialization is the ability of the organizer of the Kawi Smara innovation program in Klungkung Regency to disseminate the program, so that information on the Kawi Smara innovation program can be conveyed to the public. From a number of research results, by looking at the conditions in the field related to the method used by the organizers in providing Kawi Smara innovation program socialization in Klungkung Regency, it can be concluded that the Kawi Smara innovation program on Indicators This program has not been maximally implemented, socialization has been carried out through meetings conducted by the Department of Population and Civil Registration of Klungkung Regency to villages in Klungkung Regency only in 2017 only, the socialization is not optimal because it is not carried out sustainably, the socialization also does not invite traditional bendesa whereas customary bendesa knows and validates every traditional marriages that exist in each of their customary territories, especially in Balinese Hinduism. The Office of Population and Civil Registry of Klungkung Regency as the program organizer has indeed provided information to the entire community and disseminated through television, web, social media and print media, this also needs to be carried out continuously, so that every community in Klungkung Regency is expected to know the ease given in this Kawi Smara program and also know the requirements.

3. The purpose of the program is the extent of conformity between the results of the program with the program objectives that have been set previously. According to Duncan 
in Steers $(1985$, p. 53) states that the achievement of goals is the overall effort to achieve goals must be seen as a process. Therefore, in order to achieve the ultimate goal more secure, phasing is needed both in the sense of phasing the achievement of its parts and phasing in the meaning of its periodization. Achievement of goals consists of several factors, namely the time period and goals which are concrete targets.

Indicators of program objectives, the achievement of program objectives are used to see the extent of conformity between the results of the program with the program objectives that have been set previously in the Kawi Smara innovation program in Klungkung Regency. The Kawi Smara Innovation program is a service for giving a marriage certificate to a married couple during a marriage ceremony. The Kawi Smara innovation program is one of the innovation programs implemented by the office of population and Civil Registration of Klungkung Regency in order to provide the best service to the community. This program was determined by Decree of the Head of the Office of Population and Civil Registration of Klungkung Regency Number 18 of 2017 concerning the Program Acceleration of Increasing Coverage of Population Documents. The goals of the Kawi Smara Innovation Program are: 1. Facilitate the community to get a marriage certificate; 2. Increasing the scope of ownership of marriage certificate; 3 . Ensure the legality of community marriages.

The results of the study can be concluded that the Kawi Smara innovation program on the indicators of the objectives of this program are already effective in quality but the quantity is still not maximal, of the three goals of the Kawi Smara innovation program in order to facilitate obtaining a marriage certificate has been achieved, the aim of ensuring the legality of marriage has been achieved while for the purpose of increasing the scope of ownership of a marriage certificate has not been reached to the maximum. For the purpose of facilitating the community to obtain a marriage certificate it has been proven by the presence of the Population Service in every invitation Kawi Smara wherever and whenever and without cost, this greatly facilitates the people who carry out marriage to immediately get a marriage certificate. For the purpose of increasing the scope of ownership of a marriage certificate has not been reached to the maximum, based on data obtained by researchers at the Office of Population and Civil Registry of Klungkung Regency that the number of 
ownership of a marriage certificate in the Regency is still low, an increase in the number of marriage certificate ownership due to the Kawi Smara innovation program is not too influential on increasing the number of marital deeds. In 2017, Kawi Smara only served 125 or $11.98 \%$ of the people who carried out the marriage, while in 2018, Kawi Smara only served 255 or $25.02 \%$ of the people who implemented marriage. For coverage of ownership of a marriage certificate in 2018 , only 37,320 or $66.58 \%$ of the number of married couples, this proves that the results of the implementation of the Kawi Smara innovation program have not maximally affected the increased coverage of marriage certificate ownership.

4. Program monitoring, i.e. activities carried out after the program is implemented as a form of attention to program participants. Furthermore, according to Winardi (2010, p. 7), supervision includes the act of checking and comparing the results achieved with the standards outlined. If the results achieved deviate from applicable standards corrective action is necessary to improve it. Furthermore, according to Bohari (1992, p. 3) supervision is a form of inspection or control of the party more to his subordinates. Siagian (2014, p. 213) states that supervision is a process of observation rather than the implementation of all organizational activities to ensure that the work being carried out goes according to a predetermined plan.

The results of the study can be concluded that the Kawi Smara innovation program on program supervision indicators has not been maximized, the results of the study concluded that the supervision or monitoring of the Kawi Smara program has been carried out by the program organizers and related stakeholders involved in this Kawi Smara program but not yet maximally, observation or supervision what is effectively carried out by the service provider is direct observation of the service recipient or can go through the village office, so that what is an obstacle in implementing this innovation program can be found a solution.

Based on the discussion above, it can be concluded that the implementation of the Kawi Smara innovation program has proven to be effective in quality, helping to make it easier for the community to obtain a marriage certificate but in terms of quantity the results are not yet optimal. In the indicator of the accuracy of the target of this Kawi Smara innovation program the quality is effective, but in terms of the results are not yet maximal, 
this is evidenced by the low percentage of people who carry out marriages that participate in the Kawi Smara innovation program compared to those who carry out marriages. Kawi Smara's innovation program on Indicators This program has not been maximized in quantity, the socialization has not been maximized because it is not carried out in a sustainable manner, the socialization also does not invite customary objects, even though customary objects know and authorize every marriage in each of their customary territories, especially Balinese Hindu marriage. The Kawi Smara innovation program on the indicators of program objectives has not yet been achieved, in the aim of facilitating the community to obtain a marriage certificate, it has been achieved, while the goal of increasing the amount of ownership of a marriage certificate has not been maximized because this program does not significantly affect the increase in the number of marriage certificate ownership, for the purpose of ensuring the legality of community marriages has been achieved because every community that carries out a marriage ceremony and follows the Kawi Smara program, the marriage that is carried out is automatically registered by the Office of Population and Civil Registration of the Klungkung Regency and is legally valid. In the program monitoring indicator, Kawi Smara has been carried out by the program organizers and related stakeholders involved in this Kawi Smara program, but it has not been maximized, effective observation or supervision carried out by the service provider is direct observation to the service recipient or through the village office, so what is the supervision or monitoring of the program is an obstacle in the implementation of this innovation program can look for a solution.

Factors inhibiting the Effectiveness of the Implementation of the Kawi Smara Innovation Program in Improving the Quality of Public Services at the Office of Population and Civil Registration of Klungkung Regency

The Kawi Smara innovation program still has shortcomings and obstacles in its implementation. To overcome the problems that hamper the implementation of the Kawi Smara innovation program, solutions can be given as follows: 
1. Lack of Socialization program socialization is the starting point that determines success in achieving its goals, therefore program socialization must be carried out in a planned and systematic manner so that planned objectives are achieved well, it happens because the better the program's socialization process will be better the public's understanding of the concept and the purpose of a program. The Office of Population and Civil Registry of Klungkung Regency should carry out socialization through meetings that are held on an ongoing basis by inviting all customary villages and villages in Klungkung Regency, because the success of this program is also very dependent on the existing stakeholders, with socialization to the Perbekel / Village head and It is hoped that the information on this program will continue and be socialized again at meetings in the village and also in the villages in adat/ traditional villages and banjar adat. Socialization through print and electronic media must also be carried out continuously so that information about the implementation of this innovation program can be conveyed to the entire community of Klungkung Regency;

2. Public awareness To increase public awareness of the importance of marriage registration and having a marriage certificate, the Office of Population and Civil Registry of Klungkung Regency can carry out socialization on an ongoing basis through meeting meetings, outreach through print and electronic media, program monitoring and evaluation directly to service recipients or through the office village;

3. Budget Limitations Budget constraints are the most urgent issue in any organizational structure, the budget is the main intake of a policy and program towards the substantive goals of the policy itself. In its implementation, the Kawi Smara innovation program is constrained by budget constraints, especially the budget in the socialization and evaluation monitoring. The budget for socialization and evaluation monitoring should be prioritized by the Klungkung District Government especially the Klungkung Regency Population and Civil Registry Office.

From the discussion above it can be concluded that the inhibiting factors for the effectiveness of the Kawi Smara innovation program are the lack of socialization, low public awareness and budget constraints, the three inhibiting factors have caused the 
implementation of the Kawi Smara innovation program to not run optimally, the three inhibiting factors above are interrelated, things The main thing to overcome this problem is the commitment of the Office of Population and Civil Registration of Klungkung Regency to prioritize the budget for socialization, monitoring and evaluation activities, with the socialization, monitoring and evaluation expected to increase public awareness of the importance of marriage registration, so that an increase in Kawi Smara services and Increasing the scope of ownership of a marriage certificate in Klungkung Regency so as to improve the quality of public services, especially services in the field of civil registration.

\section{Conclusions}

\section{Summary}

Based on the results of the study it can be concluded that:

1. The implementation of the Kawi Smara innovation program has been effective in terms of service quality, this innovation program has proven to be very helpful in facilitating the community to obtain a marriage certificate, this innovation program has the advantage of speeding the process of receiving a marriage certificate, Kawi Smara is a solution for people who want to they carry out the marriage ceremony immediately get their marriage certificate. However, the achievement of the aspect of quantity has not been maximized.

2. The factors which hampered the effectiveness of the implementation of the Kawi Smara innovation program at the Department of Population and Civil Registration of Klungkung Regency were:

1) Less Socialization the Kawi Smara innovation program is one of the innovations of the Department of Population and Civil Registration of Klungkung Regency which has only been running for two years. In the implementation of the dissemination of the innovation program has not been effective, socialization through meetings only held in 2017 and not carried out sustainably. In this socialization only invited village officials only and did not invite custom village, the customary village party should also be invited because custom village knows and validates every marriage 
ceremony carried out by Balinese Hindus in general. As a result there are still many people who do not know about the Kawi Smara innovation program, the requirements and also the costs. This can be proven by the low percentage of people who have joined the Kawi Smara program,

2) Community Awareness one of the factors that also influences the implementation of government service tasks in the Klungkung Regency is the community awareness factor. Public awareness is intended to be aware of the importance of registering marriages, marriages that have not been recorded causing marriages are considered invalid. The marriage certificate problem is a complicated problem for the community where the community is reluctant to take care of the marriage certificate because of the lack of information about the importance of marriage registration and also its requirements, distance issues are also a problem for the community, especially people who live in Nusa Penida island as Subdistrict which are very costly to get to at the Office of Population and Civil Registry of Klungkung Regency.

3) Budget Limitations budget limitations in the Klungkung Regency's Population and Civil Registry Office have caused Kawi Smara's innovation program monitoring and evaluation activities to not be carried out in a sustainable manner. The socialization, monitoring and evaluation of the Kawi Smara innovation program can only be carried out in 2017, while in 2018 the socialization, monitoring and evaluation of the Kawi Smara innovation program cannot be carried out due to budget constraints.

\section{Suggestions}

Based on these conclusions, the following suggestions can be given:

1. The Kawi Smara Innovation Program is indeed helping and facilitating the people who carry out marriages to get a marriage certificate immediately. Deficiencies and obstacles in implementing this program must be immediately overcome by the Office of Population and Civil Registration of Klungkung Regency, so that what is the goal of implementing this program can be achieved so that even though marriages are conducted 
according to religion and belief, in the eyes of the marital state it is considered not yet valid if it has not been recorded by the Population and Civil Registry Office.

The implementation of the Kawi Smara innovation program is effective and can improve the quality of public services, especially in the field of civil registration services.

2. To overcome the problems that hamper the implementation of the Kawi Smara innovation program, solutions can be given as follows:

1) The Office of Population and Civil Registry of Klungkung Regency should carry out socialization in a sustainable manner either through meetings or meetings by inviting all stakeholders as well as through print and electronic media so that information about the implementation of this innovation program can be conveyed to the entire community of Klungkung Regency;

2) To increase public awareness of the importance of marriage registration, the Office of Population and Civil Registry of Klungkung Regency can conduct socialization, monitoring and evaluation so that information about the importance of marriage registration can be conveyed and problems in its implementation can be immediately addressed;

3) For the continuation of the implementation of the Kawi Smara program, the Government of Klungkung Regency in particular the Office of Population and Civil Registry of Klungkung Regency must have a commitment in providing budgets, especially budgets for socialization, monitoring and evaluation.

\section{References}

Akbar \& Usman (2009). Metode Penelitian Sosial. Jakarta, Bumi Aksara.

Bungin, Burhan (2008). Penelitian Kualitatif : Komunikasi, Ekonomi, Kebijakan Publik dan

Ilmu Sosial Lainnya, Edisi Pertama Cetakan Ke-2.Jakarta,Kencana Prenada Media Group.

Bohari (1992). Pengawasan Keuangan Negara. Jakarta, Rajawali Press.

Kowaas Agrio Scivo, Novie Pioh and Neni Kumayas (2017). Efektivitas Pelaksanaan Tomohon International Flower Festival Di Kota Tomohon, EKSEKUTIF Volume 2 No. 2 
Tahun 2017 ISSN : 2337 - 5736, Jurnal Jurusan Ilmu Pemerintahan Fakultas Ilmu Sosial Dan Politik Universitas Sam Ratulangi.

Makmur (2011). Efektivitas Kebijakan Kelembagaan Pengawasan. Bandung, Refika Aditama.

Mardikonto, Totok dan Poerwoko Subianto, (2013). Pemberdayaan Masyarakat dalam Perspektif kebijakan Publik, Bandung, Alfabeta

Richard M, Steers, (1985), Manajemen Publik, Yogyakarta, BBPE.

Sondang P. Siagian (2014). Manajemen Sumber Daya Manusia. Jakarta, Bumi Aksara.

Sugiyono (2005). Memahami Penelitian Kualitatif. Bandung, Alfabeta. (2006). Metode Penelitian Administrasi : Dilengkapi dengan Metode R\&D, Edisi Revisi Cetakan ke 14, CV. Alfabeta, Bandung

Steers, M Richard (1985). Efektivitas Organisasi Perusahaan. Jakarta, Erlangga

Winardi (1992). Motivasi, Permotivasian dan Manajemen. Edisi Kesatu, Cetakan kesatu. Jakarta, PT. Raja Grafindo Persada.

LKJIP Dinas Kependudukan dan Catatan Sipil Kabupaten Klungkung Tahun 2016.

LKJIP Dinas Kependudukan dan Pencatatan Sipil Kabupaten Klungkung Tahun 2017. www.disdukcapil.klungkungkab.go.id. 